\title{
Research on Risk Management of Gongbei Tunnel Engineering Excavation Team
}

\author{
Dongchen Guo \\ China Academy of Transportation Sciences, Beijing, China
}

\begin{abstract}
Gongbei tunnel is the key project of Hong kong-Zhuhai-macao bridge Zhuhai connecting line. The tunnel adopts frozen Curve pipe curtain digging method. In order to ensure the safety of Gongbei tunnel engineering, the rsik management of tunnel excavation team has studied. It has studied on the relevancy between on the organizational structure, rules and regulations, education and training, assessment of rewards and punishments of construction team. Then it make sure the best relevancy risk to plan the risk prevention and controlling measures. Finally, the safety management strategy has targeted to the Excavation team. After practical application, the excavation team of Gongbei tunnel has achieved all-round and focused risk management, which has guided the implementation of the excavation work.
\end{abstract}

\section{Preface}

Gongbei tunnel is the key control project of Hong kongZhuhai-Macao bridge Zhuhai connecting line. The tunnel's starting point is located in south of Zhuhai Gongbei bay and east of the Macau peninsula waters, the terminal is located in the fifth branch management area of Guangdong provincial public security frontier. It picks up the Gongbei bay bridge after artificial island of the Zhuhai-Macau port, and traverses Gongbei port, which is the largest land road port of China.

Tunnel excavation adopts the $255 \mathrm{~m}$ curve pipe curtain and frozen excavation method, which is so complicated and high risk. This requires the construction team to work closely together. Considering the particularity of its construction technology, it is necessary to optimize the configuration of the crew, and then put forward the targeted control measures and requirements.

\section{Project overview and research ideas}

\subsection{Overview of Gongbei tunnel}

The construction conditions of tunnel excavation are extremely complicated.

First, geological conditions are complex. The tunnel is built in the marine, marine-terrigenous and terrigenous facies strata. The average thickness is about $28 \sim 35 \mathrm{~m}$, and the soft soil layer is dominated by Marine sediments. It has multi-layer, large thickness, wide distribution, high compressibility, high sensitivity, high moisture content, high porosity ratio, low strength, etc. These factors make the tunnel have many disadvantages in the stability of surrounding rock, design of support and construction.
Second, it has high political sensitivity. It needs to traverse the first land port that have the daily passenger flow of 250,000 passengers (the peak of 300,000) and the average daily flow of 7,000 vehicles (the peak of 10,000 vehicles).

Third, the surface buildings are dense and important The outer edge of the tube was only $0.75 \mathrm{~m}$ from the pile foundation of the Macau joint inspection building. The minimum distance of the Zhuhai Gongbei station is less than $24 \mathrm{~m}$. These are very important public buildings.

Fourth, the power, telecommunication, water supply and drainage network are numerous in the area of tunnel line.

Therefore, the tunnel construction adopts curvilinear curtain to freeze soil construction method.

\subsection{Research approach}

- Through the investigation of the basic situation of the excavation team, the factor $M$ affecting the safety management of the construction crew were analyzed.

- Through the analysis of the excavation operation process, the risk analysis is carried out to form the construction safety factor $\mathrm{N}$.

- Through correlation analysis between factor $\mathrm{M}$ and factor $\mathrm{N}$, to carry out the, the key safety management factors that influence the excavation of Gongbei tunnel are determined. Furthermore, the related management countermeasures are developed to guide the safety operation of the team.

\section{Construction personnel influence factor analysis (factor $M$ )}




\subsection{Tunnel excavation personnel analysis}

Based on the basic information of 375 tunnel construction personnel, the analysis of the demographic characteristics of the construction crew of tunnel engineering was concluded [1], [2].

Gender: in tunnel engineering construction group, mainly male, female mainly engaged in logistics. About $96.3 \%$ is men and $3.7 \%$ is women. The gender ratio is about 26:1

Age: among the tunnel builders, the maximum number of employees aged 40 to 49 was 137 , accounting for $36.5 \%$ of the total. A total of 78 persons under 30 years of age accounted for $20.8 \%$. Five people over the age of 60 accounted for $1.3 \%$. The age structure is reasonable.

Education background: The construction personnel of high school and above are responsible for $11.5 \%$. The construction personnel of the junior high school and the following qualifications account for $88.5 \%$. The ratio of high school and above education to junior high school and below is 1:7.7.

Construction experience: the tunnel construction personnel have rich construction experience. People with more than five years of experience have a ratio of $82.4 \%$.

Staff mobility: tunnel builders who work less 6 months accounted for about $60.7 \%$ in a single project. The staff mobility is frequent.

\subsection{Analysis of safety factors}

The factors that affect the safety on construction team are multifaceted. According to the four elements of safety management that include human, objects, environment and management, the analysis of influencing factors was carried out.

Human factors. The construction group is the smallest unit in the construction organization. The team leader is responsible for the daily management and safety management of the team. Therefore, the selection of group leader is the key of group organization and safety management. $\mathrm{n}$ addition, the workers' skill level and safety ability determine whether the construction site is safe. Therefore, construction personnel ability is an important factor in the safety management of construction crew.

Objective factors. The main items involved in construction team include mechanical equipment, tools, construction materials, and so on. The main factors affecting the safety of construction are the lack of safety equipment, failure, unqualified tools and construction materials.

Environmental factors. The environment of the tunnel excavation group is complex and changeable. The excavation environment of Gongbei tunnel is mainly the enclosed space formed by the pipe curtain and the support after the frozen soil. The main influencing factors are the freezing injury caused by the curtain, the construction injuries in the construction cross operation environment, such as mechanical injury, object strike, high fall, etc.

Managerial Factors. The safety management system of the construction project department is relatively perfect, but for the construction team, the management system is imperfect and the target is poor, and many systems are not in place.

In the above influencing factors, the objective factors can be eliminated by inspection and acceptance. Other factors, such as human factors (include team leader, construction personnel), environmental factors (include low temperature environment, cross-operation environment) and management factors (include responsibility system, education training, assessment, rewards and punishments), are all factors affecting the safety of Gongbei tunnel excavation team.

\section{Influence factors of tunnel excavation process (factor $\mathrm{N}$ )}

\subsection{Decomposition of excavation process}

There are three main stages.

- Subsurface excavation and secondary lining. It includes the soil grouting reinforcement in the hole, the excavation of the underground continuous wall, the excavation of the hole, the water stop between the pipes, frozen exterior-protected construction, the initial support, the temporary support, the secondary lining, etc.

- Third lining. It includes the dismantling of the temporary support, the third lining in sections, the thawing settlement grouting, and the filling of water mud in even tube, etc.

- Ancillary and traffic engineering in the cave.

The construction paragraph of tunnel excavation in Gongbei tunnel is shown in Figure 1.

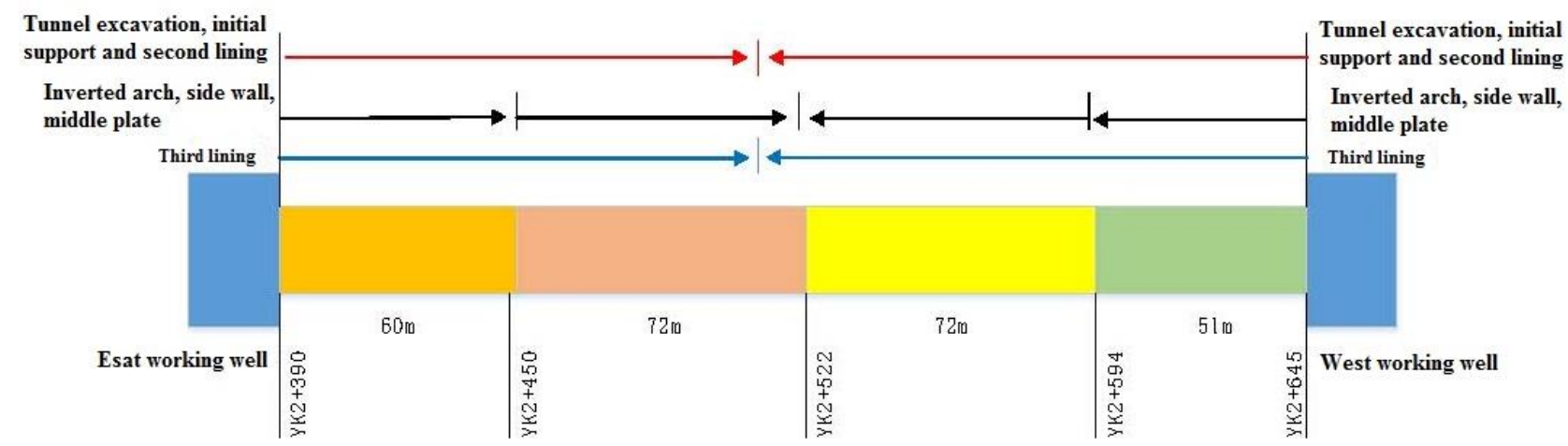

Figure 1. The section of the excavation works of Gongbei tunnel construction. 


\subsection{Analysis of safety factors}

Based on the tunnel construction process, the paper analyzes the risk source, the risk factors and the types of accidents that may occur, and puts forward the corresponding risk control measures. It is shown in "Table $1 ”$.

Table 1. Safety risk identification and control measures during excavation of Gongbei tunnel.

\begin{tabular}{|c|c|c|c|c|}
\hline SN & Content & Risk Factor & $\begin{array}{l}\text { Accident } \\
\text { Pattern }\end{array}$ & Control Measures \\
\hline 1 & $\begin{array}{l}\text { Clean the } \\
\text { roof loose } \\
\text { soil }\end{array}$ & $\begin{array}{l}\text { Top cleaning } \\
\text { is not } \\
\text { thorough; } \\
\text { Exposed soil } \\
\text { is instability; } \\
\text { Loose stone. }\end{array}$ & $\begin{array}{l}\text { Falling } \\
\text { accidents; } \\
\text { object } \\
\text { strike. }\end{array}$ & $\begin{array}{l}\text { Set warning area; } \\
\text { Remove loose stone and } \\
\text { concrete blocks before } \\
\text { work; } \\
\text { Provide adequate lighting } \\
\text { for the construction area. }\end{array}$ \\
\hline 2 & $\begin{array}{l}\text { supportin } \\
\text { g erection }\end{array}$ & $\begin{array}{l}\text { Use the loader } \\
\text { as the } \\
\text { construction } \\
\text { platform; } \\
\text { The steel arch } \\
\text { is not strong } \\
\text { and the } \\
\text { spacing is too } \\
\text { large; } \\
\text { The arch foot } \\
\text { is suspended } \\
\text { or placed on } \\
\text { waste residue. }\end{array}$ & $\begin{array}{l}\text { Falling } \\
\text { accidents; } \\
\text { collapse } \\
\text { accident. }\end{array}$ & $\begin{array}{l}\text { Use a safe and reliable } \\
\text { working platform; } \\
\text { The steel arch should be } \\
\text { connected in time to } \\
\text { prevent dumping; } \\
\text { The suspended part of the } \\
\text { arch and the wall must be } \\
\text { filled with concrete. }\end{array}$ \\
\hline 3 & $\begin{array}{l}\text { Frozen } \\
\text { earth } \\
\text { excavatio } \\
\text { n } \\
\text { (artificial } \\
\text { mating } \\
\text { machiner } \\
\text { y) }\end{array}$ & $\begin{array}{l}\text { Dust; } \\
\text { Knocked over; } \\
\text { Noise damage } \\
\text { and visual } \\
\text { impairment; } \\
\text { Continue } \\
\text { drilling in the } \\
\text { rejected hole. }\end{array}$ & $\begin{array}{l}\text { Falling } \\
\text { accidents; } \\
\text { collapse } \\
\text { accident; } \\
\text { water and } \\
\text { mud } \\
\text { burst; } \\
\text { explosive } \\
\text { accident. }\end{array}$ & $\begin{array}{l}\text { Choose the safe } \\
\text { construction site and } \\
\text { check the safety condition } \\
\text { of the drill before drilling; } \\
\text { The construction site } \\
\text { safety work protection is } \\
\text { done ; } \\
\text { Wear labor protection } \\
\text { articles. }\end{array}$ \\
\hline 4 & $\begin{array}{l}\text { preliminar } \\
\text { y bracing }\end{array}$ & $\begin{array}{l}\text { Not wearing } \\
\text { protective } \\
\text { equipment or } \\
\text { incorrect use; } \\
\text { Dust; } \\
\text { The concrete } \\
\text { rebound. }\end{array}$ & $\begin{array}{l}\text { object } \\
\text { strike; } \\
\text { Falling } \\
\text { accidents. }\end{array}$ & $\begin{array}{l}\text { Wear personal protective } \\
\text { equipment; } \\
\text { Do not enter the } \\
\text { construction area, before } \\
\text { the nozzle of construction } \\
\text { is strictly prohibited; } \\
\text { Use a working platform. }\end{array}$ \\
\hline 5 & $\begin{array}{l}\text { dregs } \\
\text { transporta } \\
\text { tion }\end{array}$ & $\begin{array}{l}\text { Mechanical } \\
\text { and human } \\
\text { cross-work; } \\
\text { Collapse of } \\
\text { surrounding } \\
\text { rock; } \\
\text { The vehicle } \\
\text { slidng, } \\
\text { overturn and } \\
\text { collision; } \\
\text { Dust } \\
\text { exceeded. }\end{array}$ & $\begin{array}{l}\text { vehicle } \\
\text { injuries. }\end{array}$ & $\begin{array}{l}\text { Setting up a warning zone } \\
\text { in a dregs area; } \\
\text { The loading and unloading } \\
\text { operation should be } \\
\text { directed by special } \\
\text { persons; } \\
\text { Loose rocks should be } \\
\text { dealt with first; } \\
\text { It is not allowed to mix; } \\
\text { It is strictly forbidden to } \\
\text { overload, exceed limit and } \\
\text { speed; } \\
\text { Set tunnel pedestrian and } \\
\text { vehicle access. }\end{array}$ \\
\hline 6 & $\begin{array}{l}\text { cross- } \\
\text { operation }\end{array}$ & $\begin{array}{l}\text { The } \\
\text { construction } \\
\text { sequence is } \\
\text { unreasonable; } \\
\text { Excavators } \\
\text { and } \\
\text { mechanical } \\
\text { arrangements } \\
\text { do not meet } \\
\text { the flow of } \\
\text { water; } \\
\text { The layout of } \\
\text { excavation is }\end{array}$ & $\begin{array}{l}\text { object } \\
\text { strike; } \\
\text { vehicle } \\
\text { injuries. }\end{array}$ & $\begin{array}{l}\text { Construction machinery } \\
\text { and vehicles should be } \\
\text { covered with reflective } \\
\text { film outside the body; } \\
\text { The speed of construction } \\
\text { machinery and vehicles } \\
\text { must not exceed } 5 \mathrm{~km} / \mathrm{h} \text {; } \\
\text { The construction } \\
\text { machinery and vehicles } \\
\text { should turn on headlights } \\
\text { when driving; } \\
\text { Construction personnel } \\
\text { should wear safety }\end{array}$ \\
\hline
\end{tabular}

\begin{tabular}{|l|l|l|l|l|}
\hline SN & Content & Risk Factor & $\begin{array}{l}\text { Accident } \\
\text { Pattern }\end{array}$ & \multicolumn{1}{|c|}{ Control Measures } \\
\hline & & $\begin{array}{l}\text { not } \\
\text { reasonable; } \\
\text { The ramp } \\
\text { between the } \\
\text { steps is too } \\
\text { steep. }\end{array}$ & & $\begin{array}{l}\text { reflective helmet and } \\
\text { reflective vest; } \\
\text { A movable reflective } \\
\text { warning sign should be } \\
\text { placed on the upper and } \\
\text { lower steps to alert } \\
\text { drivers. }\end{array}$ \\
\hline
\end{tabular}

Through risk analysis, we can draw the influence factors of affect the process of construction safety, mainly has to clean the loose roof soil (include soil instability, top cleaning), the erection of support (include mechanical work, support interval, unstable arch foot), frozen soil excavation (include dust, noise, drilling, mechanical operation), primary support (include individual protection, dust, and concrete), sediment transport (include crossover operation, the instability of surrounding rock, slag discharge car, dust), crossover operation sequence (include construction sequence, builders, machinery, layout) and other factors.

\section{Correlation analysis of influencing factors}

For the above factors, we designed a questionnaire for the front-line construction personnel. A total of 1214 valid questionnaires were collected.

Through questionnaire survey, the relevant information of each influencing factor was calculated.

Then using SPSS software to carry out data analysis, the related coefficients of each influencing factor were obtained [3]-[8]. This is shown in "Table 2".

Table 2. The related coefficient between the safety factors of Gongbei tunnel excavation process.

\begin{tabular}{|c|c|c|c|c|c|c|c|c|c|}
\hline \multirow{2}{*}{ Factor N } & \multirow{2}{*}{${ }_{\mathrm{N}}^{\mathrm{M}}$} & \multicolumn{2}{|c|}{$\begin{array}{l}\text { Human } \\
\text { factors }\end{array}$} & \multicolumn{2}{|c|}{$\begin{array}{l}\text { Objective } \\
\text { factors }\end{array}$} & \multicolumn{4}{|c|}{ Managerial Factors } \\
\hline & & $\begin{array}{l}\text { Group } \\
\text { leader }\end{array}$ & $\begin{array}{l}\text { Front- } \\
\text { line } \\
\text { constr } \\
\text { uctors }\end{array}$ & $\begin{array}{l}\text { Low } \\
\text { temper } \\
\text { ature }\end{array}$ & $\begin{array}{l}\text { Cross } \\
\text { pperati } \\
\text { on }\end{array}$ & $\begin{array}{l}\text { Responsi } \\
\text { pility } \\
\text { system }\end{array}$ & $\begin{array}{l}\text { Educat } \\
\text { ional } \\
\text { trainin } \\
g\end{array}$ & $\begin{array}{l}\text { Assess } \\
\text { ment }\end{array}$ & $\begin{array}{l}\text { Rewa } \\
\text { rds } \\
\text { and } \\
\text { punis } \\
\text { hmen } \\
\text { ts }\end{array}$ \\
\hline \multirow{2}{*}{$\begin{array}{c}\text { Clean } \\
\text { the roof } \\
\text { loose } \\
\text { soil }\end{array}$} & \begin{tabular}{|c} 
Soil \\
instabilit \\
$y$
\end{tabular} & 0.912 & 0.812 & 0 & 0 & 0.856 & 0.658 & 0.328 & 0.786 \\
\hline & \begin{tabular}{|c|} 
Top \\
cleaning
\end{tabular} & 0.911 & 0.885 & 0 & 0 & 0.754 & 0.645 & 0.355 & 0.812 \\
\hline \multirow{3}{*}{$\begin{array}{l}\text { Support } \\
\text { ing } \\
\text { erection }\end{array}$} & $\begin{array}{l}\text { Mechani } \\
\text { cal work }\end{array}$ & 0.523 & 0.964 & 0 & 0.875 & 0.823 & 0.765 & 0.576 & 0.825 \\
\hline & $\begin{array}{l}\text { Support } \\
\text { interval }\end{array}$ & 0.825 & 0.967 & 0.512 & 0 & 0.867 & 0.945 & 0.465 & 0.764 \\
\hline & $\begin{array}{l}\text { Unstable } \\
\text { arch foot }\end{array}$ & 0.852 & 0.982 & 0 & 0 & 0.853 & 0.854 & 0.532 & 0.756 \\
\hline \multirow{4}{*}{$\begin{array}{c}\text { Frozen } \\
\text { earth } \\
\text { excavati } \\
\text { on }\end{array}$} & Dust & 0.545 & 0.565 & 0 & 0 & 0.546 & 0.589 & 0.532 & 0.465 \\
\hline & Noise & 0.456 & 0.478 & 0 & 0.125 & 0.125 & 0.156 & 0.214 & 0.323 \\
\hline & $\begin{array}{l}\text { Mechani } \\
\text { cal work }\end{array}$ & 0.512 & 0.716 & 0 & 0.256 & 0.865 & 0.786 & 0.643 & 0.564 \\
\hline & \begin{tabular}{|c|} 
Drilling \\
work
\end{tabular} & 0.752 & 0.867 & 0.216 & 0.126 & 0.764 & 0.574 & 0.649 & 0.598 \\
\hline \multirow{3}{*}{$\begin{array}{l}\text { Prelimi } \\
\text { nary } \\
\text { support }\end{array}$} & Dust & 0.547 & 0.457 & 0 & 0 & 0.235 & 0.325 & 0.453 & 0.534 \\
\hline & $\begin{array}{c}\text { individua } \\
l \\
\text { protectio } \\
n\end{array}$ & 0.756 & 0.985 & 0.564 & 0.876 & 0.654 & 0.867 & 0.912 & 0.954 \\
\hline & $\begin{array}{c}\text { Concret } \\
e\end{array}$ & 0.451 & 0.549 & 0 & 0.354 & 0.239 & 0.247 & 0.258 & 0.387 \\
\hline
\end{tabular}




\begin{tabular}{|c|c|c|c|c|c|c|c|c|c|}
\hline \multirow{4}{*}{$\begin{array}{l}\text { Dregs } \\
\text { transpo } \\
\text { rtation }\end{array}$} & $\mid \begin{array}{c}\text { Cross- } \\
\text { operatio } \\
n\end{array}$ & 0.765 & 0.778 & 0 & 1 & 0.766 & 0.656 & 0.812 & 0.885 \\
\hline & \begin{tabular}{|l|} 
Surroun \\
ding \\
rock \\
failure
\end{tabular} & 0.421 & 0.873 & 0 & 0 & 0.148 & 0.471 & 0.232 & 0.321 \\
\hline & Vehicle & 0.321 & 0.857 & 0 & 0 & 0.788 & 0.786 & 0.789 & 0.879 \\
\hline & Dust & 0.347 & 0.657 & 0 & 0 & 0.235 & 0.325 & 0.453 & 0.534 \\
\hline \multirow{4}{*}{$\begin{array}{l}\text { Cross- } \\
\text { operati } \\
\text { on }\end{array}$} & \begin{tabular}{|} 
Constru \\
ction \\
sequenc \\
$e$
\end{tabular} & 0.952 & 0.912 & 0 & 1 & 0.953 & 0.904 & 0.923 & 0.954 \\
\hline & Builders & 1 & 1 & 0 & 1 & 0.852 & 0.886 & 0.876 & 0.907 \\
\hline & $\begin{array}{c}\text { Machin } \\
\text { ery }\end{array}$ & 0.765 & 0.965 & 0 & 1 & 0.854 & 0.868 & 0.829 & 0.867 \\
\hline & Layout & 0.945 & 0.911 & 0 & 1 & 0.876 & 0.852 & 0.782 & 0.813 \\
\hline
\end{tabular}

Through correlation analysis, it can be concluded that there are important factors related to the construction safety of Gongbei tunnel excavation. It mainly refers to the group leader, front-line constructors, cross-operation, construction sequence, responsibility system, education training, rewards and punishments.

\section{Safety management countermeasures of tunnel excavation team}

\subsection{Technical strategies}

According to the correlation of safety influence factors, it is suggested to select small sections and determine the reasonable excavation steps, spacing, support and types.

\subsubsection{Excavation steps}

The tunnel was eventually determined to be excavated in fourteen parts. It is divided into 5 steps: A, B, C, D and E. The steps are about $3.8 \sim 5.0 \mathrm{~m}$. It is shown in Figure 2 .

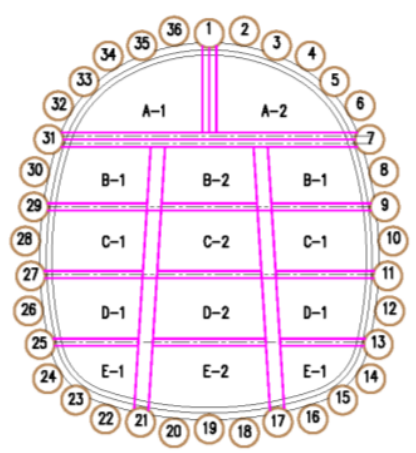

Figure 2. Tunnel excavation section layout.

\subsubsection{Excavation space}

a) The first step is to excavate a-2 guide pit first, then excavate a- 1 guide pit, and the a- 1 guide pit lags behind the a- 2 guide pit about $5 \mathrm{~m}$. $20 \mathrm{~m}$.

b) The second step is separated from the first step by

c) The third step and the second step are separated by $15 \mathrm{~m}$. d) The fourth step and the third step are separated by $15 \mathrm{~m}$.

e) The fifth and fourth steps are separated by $15 \mathrm{~m}$.

\subsubsection{Support}

a) The first step: for every $1 \sim 2$ steel spacing $(0.4 \mathrm{~m}$ spacing), the initial support and temporary support structure should be followed. After the first step of excavation is completed, the instant support molds are cast concrete and the second lining.

b) The other steps: start to make a second line when the distance is more than $10 \mathrm{~m}$.

\subsubsection{Excavation types}

a) The first step: all the holes are excavated with PC55 small excavators, with small auxiliary tools such as pneumatic picks. The residual soil is transported with the self-unloading vehicle.

b) The other steps: first, the two side headings should be opened, then the center heading to be excavated. The center heading is spaced about $5 \mathrm{~m}$ between the two side headings.

\subsection{Construction strategies}

\subsubsection{Before work}

a) The special construction plan should be prepared before the tunnel construction, and the on-site disposal plan of the construction site shall be improved, and the practice shall be organized regularly. In the construction, there shall be sufficient emergency and emergency supplies.

b) The tunnel excavation shall be adjusted according to its geological conditions, section size, suitable construction equipment, proper operation area and adjustment in the construction process.

c) Prior support should be checked before excavation, and whether the thickness of freezing meets the design requirements.

d) Before the operation of each construction process, the operation risk and safety measures shall be informed to all team members by the safety officer through the form of pre-class safety speech.

$e)$ Before the excavation of the next cycle, it is necessary to check the initial support to ensure the safety of the construction work.

f) The roof cleaning must be directed by a specialist, and lighting should have adequate illumination.Safety confirmation must be carried out after clean the top. After qualified, other workers can enter the excavation work.

\subsubsection{In the work}

a) The excavation length must be controled strictly. Meanwhile, it shall be reduced the perturbation of 
surrounding rock, and do not damage the initial support, lining structure and construction equipment.

b) After excavation, the initial support and temporary support should be made to form a full - section circular closure. It is necessary to make the second lining structure as soon as possible. In the construction, the stability of the tunnel face and the ground of the temporary vertical support are always concerned.

c) The initial support and temporary support are followed by the excavation of the guide hole to complete the structure of the supporting body. When excavating, the special person should be appointed to conduct the excavation operation, Strictly limit the mechanical operation boundary to prevent collision steel frame.

d) When using mechanical excavation, the machine should be selected according to the tunnel's section and environment, and the safe operation area shall be defined and the warning signs shall be set. Non-operating personnel are not allowed in.

e) In the case of manual excavation, the workers shall maintain the necessary safety distance and set up a special conductor.

f) When the deformation rate of surrounding rock and support system is found to be abnormal, effective measures should be taken immediately and all personnel should be evacuated from the dangerous area when the situation is serious.

\subsubsection{After the work}

a) At the end of the day, the team leader and the safety officer should count the personnel. The team leader should review the work area and find out the security risks.

b) At the time of the transfer, the situation of work completion, the risk point of the construction process, and possible safety hazards are explained to the next group. The signing procedures of the succession shall be performed.

c) The tunnel construction plan should be adjusted in time according to the geological prediction.

\subsection{Management countermeasures}

\subsubsection{Team organization}

a) Group leader selection: The group leader of Gongbei tunnel should select a person with more than 10 years of experience in construction and should not be older than 55.

b) Construction personnel requirements: A construction worker with more than 5 years experience can bring one worker who has one year working experience. People without experience in tunnel construction are not allowed to enter the excavation team.

\subsubsection{Team safety management system}

The responsibility of the post should be clearly defined, the responsibility system should be implemented, and relevant security system (such as safety education training system, safety assessment and punishment system, etc.) should be formulated, and the relevant system should be strictly implemented. We will strengthen the management of the team from the three aspects of system construction, responsibility implementation, rewards and punishments.

\section{Conclusion}

Based on information research and questionnaire survey to Gongbei tunnel construction personnel, The basic data analysis of tunnel construction personnel and the risk analysis of excavation process are carried out. Using SPSS software to carry out correlation analysis, the important factors that influence the tunnel's construction safety are obtained. Finally, the countermeasures of the construction team has been proposed. The following conclusions are obtained.

a) The important factors related to the construction safety of the tunnel excavation are obtained. There are team leader, front-line construction personnel, construction step and spacing, cross operation, responsibility system, education training, rewards and punishments.

b) In the three aspects of technical strategies, construction strategies and management countermeasures, the safety management measures of the excavation team are formulated.

c) Through the application of relevant research results, the construction quality of tunnel engineering is effectively guaranteed, and the zero casualties target of the excavation team has realized.

This paper discusses the safety management of the tunnel excavation of Gongbei tunnel in order to provide reference for the safety management of other similar projects.

\section{References}

1. GUO Dongchen, SU Xinguo, HUANG Xuewen, ZHANG Weijun, WU Linsong, "Safety Management Mode of Bridge \& Tunnel Construction Team Based on Demographic Characteristics," Transport Research, vol. 1, pp. 66-74, August 2015.

2. State Council Research Office, "Chinese migrant workers survey report,” Yanshi Press. Beijing: 2006.

3. JIANG Yizhou, LI Zhiqiang, ZHANG Weijun, WU Linsong, "Influence Analysis of Psychological Factors of Bridge \& Tunnel Builders on Operation Safety Based on SAS/SDS," Safety and Environmental Engineering, vol. 23, pp. 96-101, May 2016.

4. LIANG Zhendong, "Study on relationship of demographic characteristics with unsafe behavior and unsafe behavioral intention," Journal of Safety Science and Technology, vol. 10, pp. 46-52, January 2014. 
5. ZHAO Jun, CAI Xiang, "Demographic Characteristics in Workplace Deviance," Soft Science, vol.28, pp. 112-116, August 2014.

6. Zhang Guiqun, Fang Weihua, "Status Survey and Variance Analysis on the Beijing Scientific and Technological Workers' Job Satisfaction Index:Based on Demographic Characteristics," Journal of Beijing University of Aeronautics and Astronautics(Social Sciences Edition), vol.26, pp. 16, November 2013.

7. Zhang Guiqun, Fang Weihua, "Status Survey and Variance Analysis on the Beijing Scientific and Technological Workers' Job Satisfaction
Index:Based on Demographic Characteristics," Journal of Beijing University of Aeronautics and Astronautics(Social Sciences Edition), vol.26, pp. 16, November 2013.

8. WANG Panpan, LI Qiming, DENG Xiaopeng, "Study on Safety Competency Model of Construction Workers," China Safety Science Journal, vol.19, pp. 40-45, Augest 2009. 